\title{
FURTHER OBSERVATIONS ON PROPRIOCEPTORS IN CRUSTACEA AND A HYPOTHESIS ABOUT THEIR FUNCTION
}

\author{
By J. S. Alexandrowicz
}

The Plymouth Laboratory

(With Plate I and Text-figs. I-5)

The observations on proprioceptors in the legs of Crustacea recorded recently (Alexandrowicz \& Whitear, 1957) have shown that in these animals there are several receptor organs in the coxal region and that there is a difference in their number in the thoracico-coxal articulation. Whereas in some species, e.g. Homarus and Astacus, there are two receptor units running side by side, termed for short muscular and elastic receptor, in others, e.g. the Brachyura, only one, of muscular type, is present. It was stated, moreover, that in the latter case the arrangement of the sensory elements of this receptor exhibit certain features differing from those in the organ of the Homarus type. But the question was left open whether this particular pattern of innervation is an inherent feature of the muscular receptor when it is not associated with a second organ, and, if this is so, what inference concerning its mode of function could be deduced therefrom. It seemed, therefore, worth while to investigate the receptors in such species as Eupagurus bernhardus and Palinurus vulgaris in which, as some preliminary observations had shown, only one receptor unit is present. In the present paper are reported the results obtained with Eupagurus, which had the advantage of being easily obtainable.

\section{METHOD}

The nerves were stained with methylene blue and the method used was the same as previously recorded. The organs in Eupagurus stain readily so that a complete failure is never experienced, although the staining, as is usual with this method, is uneven. The main difficulty consists in exposing the organs in such a way that the methylene-blue solution can have free access to them and to keep all the parts of the preparation in the desired position. The usual method is to attach them to paraffin plates. Paraffin wax, however, has the disadvantage of being soluble in xylol. This is of no importance when the preparations are of such size and shape that after being stained and fixed they can be detached from the plates and remain flat up to the final stage of mounting. When, however, such objects as fine fibres pass through alcohol and xylol they usually become bent or deformed in various ways. In handling 
such preparations polyethylene ('polythene') plates proved very serviceable, since the tissues attached to them with the finest pins can be transferred into xylol and remain perfectly stretched in it. I am indebted to Mr F. A. J. Armstrong for this suggestion and for providing the plates. This method can be also used when embedding easily deformable objects; they can pass unaltered from the moment of fixation through all media, to be detached only before being transferred into the paraffin bath or even shortly before embedding. Polyethylene, however, is not yet an ideal material for similar purposes since it is affected by xylol, although very slightly. It is to be hoped that with so many kinds of plastics now being manufactured, or being invented, some of them will prove to be satisfactory in every respect.

\section{OBSERVATIONS}

In the coxal region of Eupagurus bernhardus the following receptor organs have been found: (i) the muscular receptor spanning the thoracico-coxal articulation; (ii) two innervated strands associated with the muscles levator and depressor basipoditis; and (iii) the coxo-basipodite receptor.

\section{Muscular receptors}

The muscular receptors are present, one on each side, in all five peraeopods. They have their proximal attachments in the vicinity of the ganglionic cord, but their position in relation to this cord and its main nerve trunks is different in each segment owing to the coalescence of the thoracic ganglia and various directions of the course of the trunks (Text-fig. I). In the 4th-6th thoracic segments the receptor muscle has its origin on the posterior surface of the endosternite plate limiting anteriorly the respective segments. In the 4 th segment it is near the border of the ganglionic mass and ventral to it; in the 5 th segment, in which it is more easily accessible, it is situated laterally to the ganglion and in front of the main nerve trunks (Pl. I, fig. I); in the 6th segment it is covered by thick nerves of the limb. In the 7 th and 8th segments, in which the endophragmal skeleton is greatly reduced, the receptor muscles originate on small chitinous plates and are also covered by main nerve trunks running to the legs.

The endosternite plates do not exhibit any special projections at the point where the muscles arise. In this respect Eupagurus differs from all decapods examined in which special receptor rods are present in several segments (Macrura) or at least in one of them (Brachyura).

At the proximal end of the muscle its myofibrils pass into fine, short ( $c a$. I00 $\mu$ ), connective tissue fibres which thus constitute a tendon by means of which the receptor is attached to the membrane lining the calcified chitin of the endosternite. Despite its insignificant appearance this tendon, as will be discussed later, plays an important role. From this point of origin the muscle 
runs in the direction of the anterior hinge of the basipodite to insert near the rim of the coxa. The muscle fibrils end here without passing into a tendon like that at their proximal attachment. They do not reach the calcified chitin of the coxa but insert near to it into the tissue of the articulation membrane. Alongside the muscle run connective tissue fibres which form two wider strands proximally, as in the Brachyura. Near the distal end of the muscle some of the fibres deviate sidewards to pass into the membrane of the articulation (Pl. I, fig. 3).

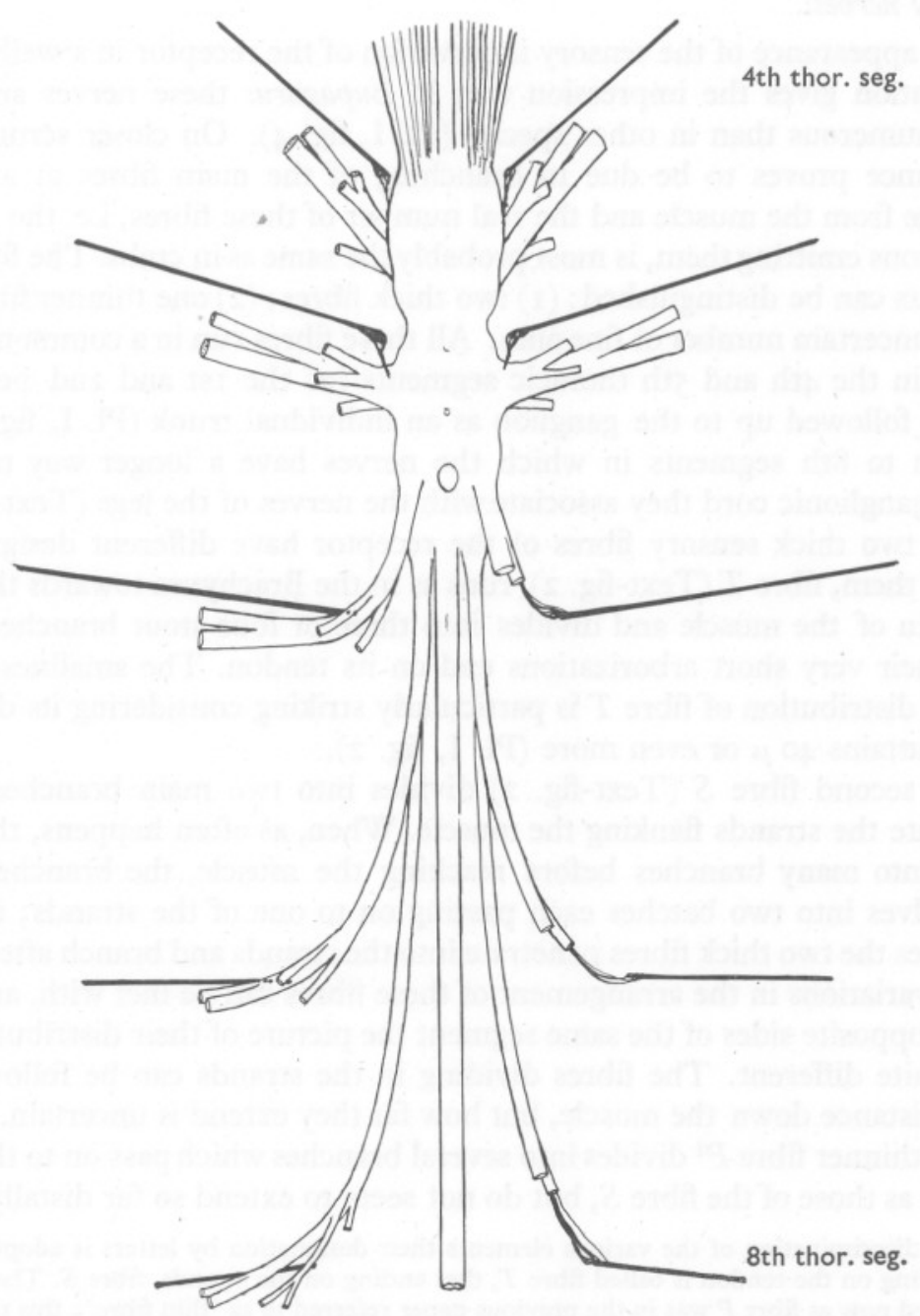

Text-fig. I. Eupagurus bernhardus. Topography of the thoracico-coxal (muscular) receptors in relation to the ganglionic cord and its main nerve trunks seen from the dorsal side. On the right side parts of the nerve trunks covering the origin of the receptors have been removed. 
Motor nerves.

Nerves

The motor fibres innervating the muscle run near the sensory nerves but do not associate with them more closely and often, especially in the posterior segments, are distinctly separated from them (Pl. I, fig. 4, mot.). The distribution of their branches follows the same pattern as in the receptors of other crustaceans.

\section{Sensory nerves.}

The appearance of the sensory innervation of the receptor in a well-stained preparation gives the impression that in Eupagurus these nerves are much more numerous than in other species (P1. I, fig. 4). On closer scrutiny this abundance proves to be due to branching of the main fibres at a greater distance from the muscle and the real number of these fibres, i.e. the number of neurons emitting them, is most probably the same as in crabs. The following elements can be distinguished: (I) two thick fibres; (2) one thinner fibre; and (3) an uncertain number of fine ones. All these fibres run in a common bundle which in the 4 th and 5 th thoracic segments (of the Ist and 2nd peraepod) can be followed up to the ganglion as an individual trunk (P1. I, fig. I). In the 6th to 8th segments in which the nerves have a longer way to travel to the ganglionic cord they associate with the nerves of the legs (Text-fig.I).

The two thick sensory fibres of the receptor have different designations. One of them, fibre $T$ (Text-fig. 2), runs as in the Brachyura towards the point of origin of the muscle and divides into three or four stout branches which with their very short arborizations end on its tendon. The smallness of the area of distribution of fibre $T$ is particularly striking considering its diameter which attains $40 \mu$ or even more (P1. I, fig. 2).

The second fibre $S$ (Text-fig. 2) divides into two main branches which innervate the strands flanking the muscle. When, as often happens, this fibre splits into many branches before reaching the muscle, the branches range themselves into two batches each passing on to one of the strands; in other instances the two thick fibres penetrate into the strands and branch afterwards. Many variations in the arrangement of these fibres can be met with, and even on the opposite sides of the same segment the picture of their distribution can look quite different. The fibres dividing in the strands can be followed for some distance down the muscle, but how far they extend is uncertain.

The thinner fibre $P^{1}$ divides into several branches which pass on to the same strands as those of the fibre $S$, but do not seem to extend so far distally as the

1 For discrimination of the various elements their designation by letters is adopted. The fibre ending on the tendon is called fibre $T$, that ending on the strands, fibre $S$. The element designated now as fibre $P$ was in the previous paper referred to as 'thin fibre'; this term does not seem to be appropriate as this fibre is not very thin and there are others which are thinner, called now fibres $F$. Such terms as 'accessory' or 'small' fibres have been avoided as they have been applied to definite elements in other instances. 
latter. Their endings are not so clearly delimited as in crabs, but there is ground for assuming that their areas of termination are independent of those of the branches of fibre $S$.

The most elusive elements are the fine fibres $F$ which can sometimes be seen running with the fibre $T$, as has also been noticed in other species. They are here distinguished as a special sort, but the possibility that they are of the same kind as the fibre $P$ or even branches of the same neuron is not excluded. As always when many nerves run side by side, there are many doubts whether a given fibre is an individual element or is only a branch of another fibre travelling in the same bundle.

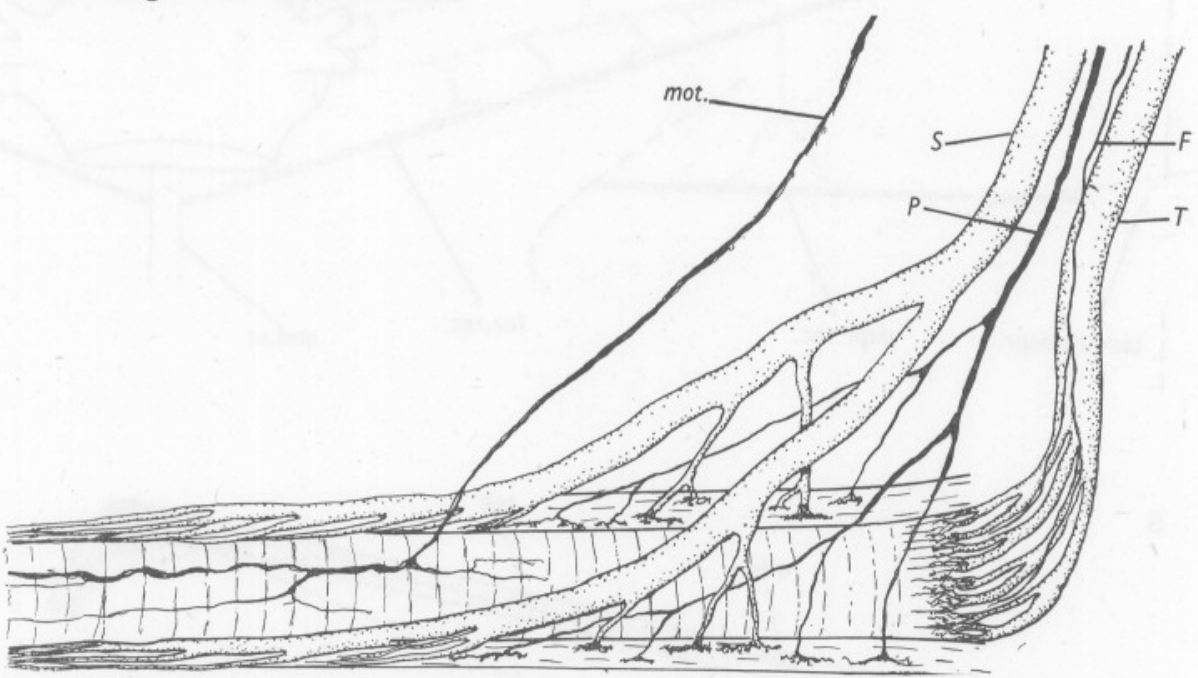

Text-fig. 2. Eupagurus bernhardus. Proximal part of a thoracico-coxal receptor. $T$, fibre ending on the tendon of the receptor muscle; $S, P$, fibres innervating the strands flanking the muscle; $F$, fine fibres accompanying the fibre $T$; mot., motor nerves of the receptor muscle.

\section{Innervated strands}

Organs of a different category, such as have been described in Homarus and Brachyura under the name of levator and depressor receptors, have also been found in Eupagurus. Their general disposition shows certain differences in this species, but they have similar relations to the muscles of the basipodite which gave rise to their designation. Each of these organs consists of a fine strand of connective tissue having elastic properties and nerve branches ending on it.

\section{Levator receptor}

The proximal attachments of the levator receptors are not the same in all segments. In the 4 th segment the strand arises on the anterior surface of the endosternite plate separating the 4 th and 5 th segment. In the 5 th and 6 th segments it arises on the plates of the endophragmal skeleton projecting dorsally in the 

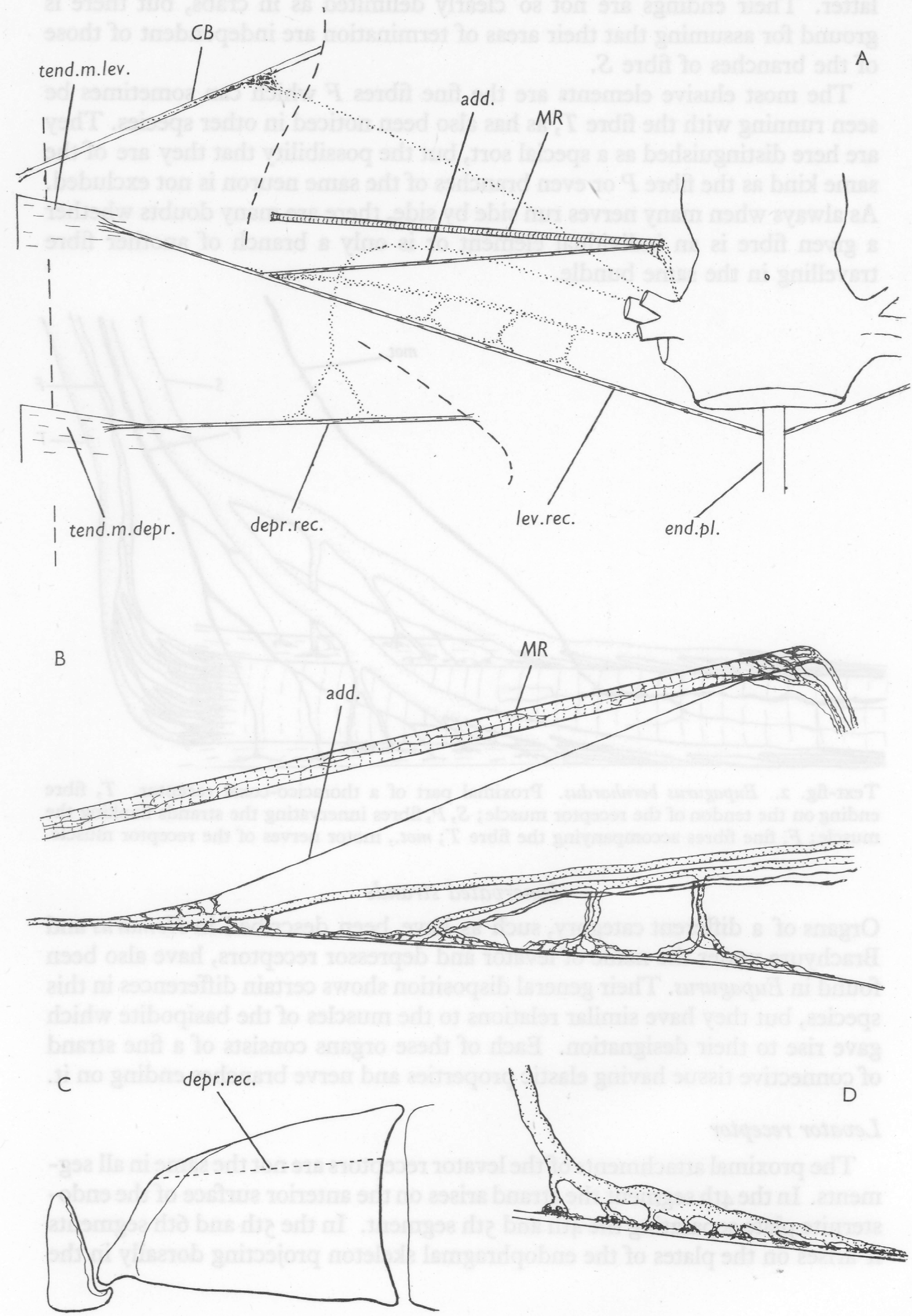

Text-fig. 3 For legend see opposite page. 
mid-line in each of the 4 th to 6th thoracic segments; the points of attachments of the strands of the opposite sides lie thus very near to each other (Textfig. $3 \mathrm{~A}$ ). In the two posterior legs they are again at a distance from one another.

In all legs the strand runs on the bundles of the ventral portion of the $\mathrm{m}$. levator basipoditis near to its anterior margin. Approaching the tendon of the muscle it splits into very fine twigs which insert on the tendon between the muscle bundles.

In the distal half of its course this strand is joined by an additional strand which arises close to the muscular receptor and, after crossing obliquely the nerve trunks of the limb, unites with the main strand at an acute angle (Text-fig. 3 A, B; Pl. I, fig. 7). The length of the main strand in the 2nd and 3 rd peraeopod of a larger specimen is about $\mathrm{I} 2 \mathrm{~mm}$ and its diameter varies from about $30 \mu$ in the middle part to some ro $\mu$ and less towards its distal end. The additional strand has a more uniform thickness in the range of 5-10 $\mu$.

The main strand is supplied by no less than three and often four nerve branches given off by a nerve trunk which also carries motor fibres for the ventral portion of $\mathrm{m}$. levator. One of the nerve branches reaches the strand always at the point where it is joined by the additional strand and the other three proximally to it and at a distance from one another (Text-fig. 3B; Pl. I, figs. 5,7 ). The three proximal branches (or two if there are three in all) consist of one thick and one or more thin fibres (Text-fig. 3 B, Pl. I, fig. 8); some of the thin fibres can sometimes be seen to run separately to the strand. In the most distal branch the thin fibres have not been noticed. The number of neurons taking part in this innervation could not be ascertained as the fibres run towards the ganglion in a common bundle,with other nerves; it seems probable that the thick fibres belong to two neurons; as to the thinner it can only be said that they appear to be emitted by more than one neuron.

The photographs (Pl. I, figs. 7,8$)$ give an idea of the striking disproportion between the calibre of the nerve fibres $(c a .50 \mu)$ and that of the strand on to which they pass not far from one another. They give off short branches which almost immediately resolve into numerous arborizations (Text-fig. 3D). Of the details of their terminations little can be seen with the ordinary microscope: in methylene-blue preparations they show irregular outlines and appear

\section{Legend Text-fig. 3}

Eupagurus bernhardus. (A)Diagram of the proprioceptors in the coxal region. $M R$, thoracicocoxal (muscular receptor); lev.rec., depr.rec., levator and depressor receptors; $C B$, coxobasipodite receptor; end.pl., plate of the endophragmal skeleton; tend.m.lev., tend.m.depr., tendons of the muscles levator and depressor. The nerves are drawn in dotted lines and the interrupted lines indicate the margins of the coxopodite. (B) Innervation of a levator receptor of the left side. Three of its nerve branches are represented as belonging to one neuron and the fourth, the most distal one, to a second neuron (the most probable disposition); add., additional strand with its proximal attachment at the origin of the muscular receptor $M R$. (C) Coxopodite of the 2nd left peraeopod from below showing the projection of the depressor receptor depr.rec. (D) Mode of branching of a thick nerve fibre on the strand of a levator (or depressor) receptor. 
confluent with one another. It is to be hoped that examination with the electron microscope for which these organs seem to be a particularly suitable object will show interesting features of the relations of the nerve fibres to each other and to the tissue of the strand.

To the question how much of the whole length of the strand is innervated no satisfactory answer can be given. The fibre entering the angle between the two strands can be followed for some distance until it fades out; it seems probable that the regions near the attachments have no innervation, but where its limit is is uncertain.

The additional strand is supplied by very short branches of the nerve fibre near its point of junction with the main strand (Text-fig. 3 B) and no other nerves in the additional strand have been noticed. It may be recalled that in Homarus the additional strand is innervated by a fibre entering its proximal end. No such fibre could be seen in Eupagurus; if there is one it could be only a fine filament which does not show in my preparations.

The levator receptors of the two posterior legs are very tiny elements and it is more difficult to expose them without damaging some of their parts. That of the 4th leg has an additional strand while in the 5 th leg this appears to be missing. The number of nerve branches in the 5 th leg seems to be reduced to three or two.

\section{Depressor receptor}

The depressor receptor has been found in the three anterior peraeopods; whether or not it is present in the two posterior ones is a doubtful point. It is situated at the ventral wall of the coxal segment and extends from the proximal border of the coxa to the tendon of $\mathrm{m}$. depressor basipoditis into which it inserts not far from its distal end. The position of its strand seen by transparency is shown in Text-fig. 3C. It runs near the anterior border of the short head of the depressor muscle arising on the rim of the coxa. Close to the bundles of this muscle is the attachment of the receptor strand the fibres of which pass here on to the tissue continuous with the membrane of the coxal articulation. It should be added that the short head of the depressor muscle is covered by longer bundles of another portion of the depressor muscle originating on the endophragmal skeleton; the receptor strand is therefore situated under these longer bundles.

The nerve carrying the fibres of this receptor is one of the branches innervating the depressor muscle. The branch of the receptor runs near the antero-ventral wall of the coxa and usually bifurcates at a distance from the strand (Pl. I, fig. 6). The two branches of this division, each containing two fibres of different calibre, pass on to the strand and behave in the same way as in the levator receptor. No adequate information about the number of fibres taking part in this innervation could be obtained; it is, however, evident that this organ has a poorer innervation than the levator receptor. 


\section{Coxo-basipodite receptor}

The coxo-basipodite receptor is present in all five peraeopods. It consists of a connective tissue strand and numerous bipolar nerve cells ending on the fibres of the strand. It looks exactly like those described in Homarus and its position is the same, viz. it originates near the dorsal hinge of the coxa and runs towards the basipodite to insert near the tendon of $\mathrm{m}$. levator $(C B$, Text-fig. $3 \mathrm{~A}$ ). The axons of the cells unite into a bundle joining the nerve which arises from the ganglion dorsally from the thickest nerve trunk of the limb and which supplies the dorsal part of the coxa.

The disposition of all receptor organs in the coxal region is shown in Textfig. 3A. Their longitudinal dimensions and their situation in relation to the mid-line of the body are drawn to scale, but they are represented diagrammatically as if lying in one plane while in fact they occupy different positions in relation to the axis of the leg.

\section{Hints on dissection}

The proprioceptors in the coxal region have to be exposed from the dorsal side. After removing the carapace and the digestive organs, the dorsal parts of the endophragmal skeleton and the muscles should be cut away until the ganglionic cord becomes exposed. The muscles covering the nerve trunks in the coxa should be removed, care being taken not to damage the ventral portion of $\mathrm{m}$. levator on which lies the levator receptor. It is not advisable to do much cleaning of the organs until the staining makes the tissues better visible. The difficulties in finding the muscular receptor in Eupagurus are aggravated by their topography, which differs in each segment. That of the and peraeopod is better taken first because it is more easily accessible. Once the organ is spotted one can proceed further with cutting out parts of the muscles, removing the blood clots, arteries, etc., but all this work must be done by stages.

The receptor of the chela is less accessible because it lies more ventral and nearer to the ganglionic mass. The organs in the 3 rd to 5 th legs are covered by nerves and these must be pulled aside or cut out if the receptors are to be exposed. The frequent mistakes can be corrected when dissecting the opposite leg. The muscular receptor of the 5 th leg, although apparently most hidden of all, proved to be quite convenient for staining and all other manipulations, as the preparation can be more easily spread and pinned down to paraffin or polyethylene plate than those from other segments. To reach the receptor all the overlying muscles must be removed until the big nerve trunks are free. Beneath them, as shown in Text-fig. $I$, is the origin of the muscle. In male animals this point lies directly in front of and not far from the end portion of the vas deferens. The receptor muscle runs close to the anterior bundles of a thin layer of the ventral portion of $\mathrm{m}$. depressor. To expose it parts of the nerves as well as the artery covering it must be removed. When the receptor is spotted it can be freed from overlying tissues along its whole length, which is $4 \mathrm{~mm}$ in the largest specimens.

The levator receptor can easily be found in the 2 nd and 3 rd peraeopod provided it has not been torn away during dissection. It can be located even before the strand itself becomes visible by the characteristic branching of its nerves. These nerves stain readily but their stain fades out in a comparatively short time.

To find the depressor receptor it is necessary to remove the muscles lying dorsal to 
that part of the coxa where the receptor strand is attached (Text-fig. 3C); great care must be taken not to damage it when cutting out the muscles in that region. It is therefore better when arriving near the receptor to pull the muscles aside, fix them with pins and observe the progress of staining until the receptor can be distinguished.

To obtain preparations of the coxo-basipodite receptor the dorsal parts of the coxa and of the basipodite should be cut out and the adhering muscles pulled aside so that the staining solution has access to the region in which this receptor is situated. When it is visible, the unnecessary tissues can be cut out to expose it better. It is also possible to get preparations with this organ in situ still connected with the central nervous system. For this purpose, in a preparation made as for staining of the muscular receptor, the posterior part of the coxa and of the basipodite should be removed and their anterior parts held in such a position that the progress of the staining of the coxo-basipodite receptor can be followed.

\section{Comparison of the proprioceptors in Eupagurus with those in other Crustacea}

The observations described above have shown that the proprioceptors in the coxal region of Eupagurus occur in the same number as in Carcinus and Cancer, and that they have similar histological structures the most remarkable feature of which is the location of the cell bodies of sensory neurons in the thoracic ganglia. The muscular receptor proved to have the same nerve elements as those in the two crabs and their disposition is basically the same; the differences in the general appearance of innervation is due to the mode of branching of nerve fibres and also to the fact that one of the elements ending on the strands flanking the muscle, the thinner fibre $P$, appears to have in Eupagurus a greater share in innervation, for it has more numerous and longer branches than in Carcinus. Major differences have been found in the topographical relations of the muscular, levator and depressor receptors, the origins of which in crabs are close together, while in Eupagurus they lie far apart. A complete isolation of the depressor receptor, as in Eupagurus, has not been hitherto seen in other species in which it has either a common attachment with the muscular receptor (Carcinus, Cancer, Palinurus), or is connected with it by an additional strand (Homarus). The levator receptor in Eupagurus resembles this organ in Homarus and Palinurus in that it has a main and an additional strand, but such disposition of nerves as is found in Eupagurus, viz. with four branches approaching the strand at a distance from one another, has not been observed before in any species.

\section{THE PROBLEM OF FUNCTION OF THE RECEPTORS IN THE COXAL REGION}

The elucidation of the functions of the receptor organs lies in the field of physiology, and hypothetical speculations about them can easily go astray if not verified by experiments. However, these organs in the legs of the Crustacea exhibit such remarkable structural differences that it seems worth while to analyse those features of their anatomy from which their function may be inferred. 
Summing up all evidence available, the following categories of proprioceptors in the legs of Crustacea can be distinguished: (I) rows of nerve cells ending on connective tissue strands; (2) muscular receptor spanning the thoracico-coxal articulation; (3) innervated strands associated with the levator and depressor muscles; (4) Barth's organ.

All these receptors are in all probability concerned with the movements of leg segments, with the possible exception of the organ described by Barth (I934), the function of which is obscure and will not be discussed here. Some of them may, moreover, be responsible for the reflex of the compensatory eye movements (Dijkgraaf, 1956).

The organs of the first category, of which there are at least seven in each peraeopod may show some differences in the arrangement of their elements, but all are made on the same principle. They are evidently stretch receptors, and being situated at the articulations are presumably designed to register the position of the adjoining segments in relation to one another. The problem why in some joints there is only one organ and in others-e.g. mero-carpopodite and carpo-propodite joints-there are two, and what are their different functions, awaits solution. In view of the ubiquity of these organs and the relation of some of them to the muscles, the hypothesis of Burke (1954) attributing to this type of receptor in the propo-dactylopodite articulation the additional function of perception of vibrations is open to doubt.

\section{Muscular receptor}

The muscular receptor in the thoracico-coxal articulation, which consists chiefly of contractile substance, must work on a different principle. In trying to understand its function the fact should be taken into consideration that it can occur either alone, or accompanied by a second receptor which by its structure belongs to the first category mentioned above.

Let us first examine the latter type in which, as in Homarus, two receptors run side by side: the one, a muscle with sensory elements ending on its tendon, and the other, a strand of connective tissue fibres with many sensory nerve cells ending on them. In the former, stimulation of sensory endings can evidently be brought about by the pulling on the tendon, and it must therefore take place each time that the muscle contracts and its myofibrils draw on the tendon. ${ }^{1}$ The contraction of this muscle occurs in all probability when the leg is moved forwards (Text-fig. 4A). This can be assumed from its position on the

\footnotetext{
1 It appears to be a general rule that the sensory elements in all the receptors known in Crustacea end not on the muscle itself, but on the connective tissue fibres. In contradiction to this Florey \& Florey (I955) stated that in the abdominal receptor organs in Astacus fluviatilis no tendinous region is present and that the processes of sensory cells end directly on the muscle. This is a mistake. These organs in Astacus have intercalated tendons at the same place as in Homarus and Palinurus, i.e. where the nerve cells distribute their arborizations. Only a small number of myofibril bundles pass uninterrupted through this region in the same way as they are known to do in some segments of Homarus.
} 
antero-ventral wall of the coxa in the vicinity of $\mathrm{m}$. promotor coxae the name of which indicates its action. It has been moreover observed in some instances that the same fibre which takes part in the motor innervation of the receptor muscle sends its branches to $\mathrm{m}$. promotor indicating the simultaneity of action of these two muscles.

The second receptor, which runs close to the muscular receptor and has similar attachments, consists of non-contractile elements and consequently can respond only when being passively extended. As can be easily demonstrated, its stretching occurs during the backward motion of the leg (Textfig. 4B). It may be therefore conjectured that the two receptors respond to the movements of the leg in the horizontal plane the muscular receptor being stimulated when the leg is moved forwards and the elastic receptor when it is pulled backwards (Text-fig. 4, Homarus $a, b$ ).

It cannot be overlooked that when the leg is moved backwards the distance between both ends of the muscular receptor is increasing and its tendon might be affected by the passive stretching of the muscle. It is, however, conceivable that this muscle may have a certain degree of slackness so that the pull on the tendon in the backward position is negligible and unable to stimulate its nerves. This view seems to be more probable than the assumption that the two organs are stimulated at one and the same time.

When the muscular receptor alone is present it is found to have a special arrangement of its nerve elements which may be called the Carcinus type, as it was first observed in this species; besides, being less complicated as in Eupagurus, it is also more suitable for diagrammatic representation. The most remarkable feature of this arrangement is the separation of the areas of termination of the two main sensory fibres. One of them, fibre $T$ (Text-fig. 4, Carcinus a), clearly shows that it is destined to respond to contractions of the muscle and should therefore be regarded as conveying impulses during the forward motion of the leg. There is no reason to suppose that the second fibre $S$ is affected at the same time for it passes into the strands flanking the muscles which have proximally only a loose relation with it and which in any event would be slackened when the muscle contracts. When, however, the leg moves backwards and the receptor becomes extended these strands must take up the strain and their stretching stimulates the endings of fibres $S, P$ (Text-fig. 4, Carcinus b). It must be assumed that here too the muscle is so adjusted that during the backward movements of the leg no response is elicited in its fibre $T$. It may be recalled that the flanking strands pass distally into the sheath surrounding the muscle and thus can give protection to the latter.

If this interpretation is correct the receptor of this type would be a remarkably effective organ capable of controlling the actions of two antagonistic muscles, viz. mm. promotor and remotor coxae. It would represent a higher stage of evolutionary development, in which only one organ is present with all its sensory neurons having their cell bodies within the central nervous 

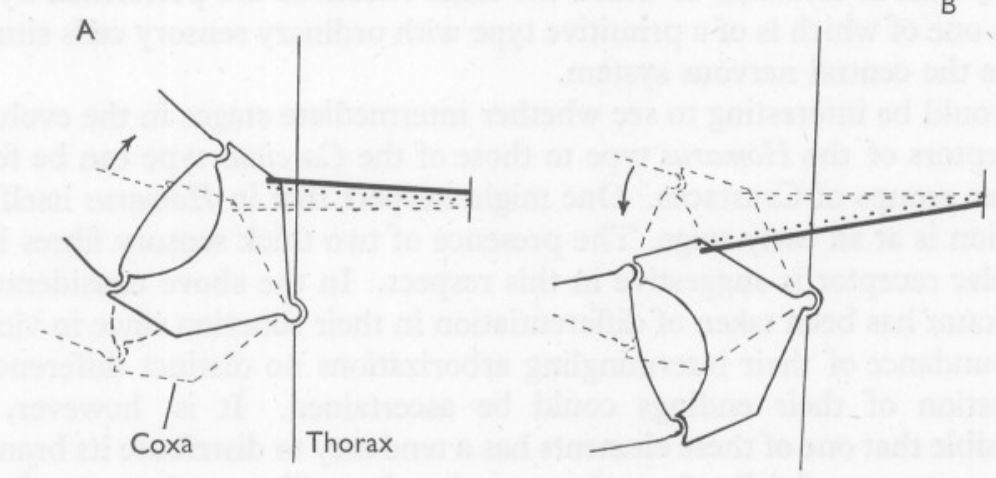

Homarus

a

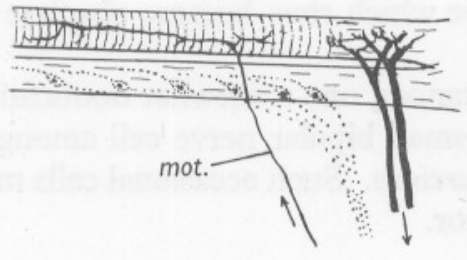

$b$

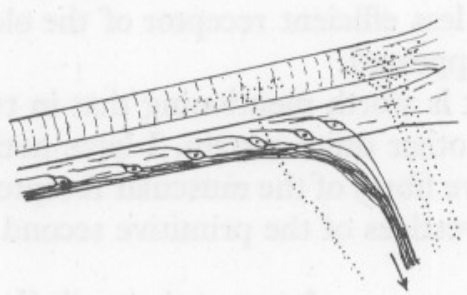

a

b
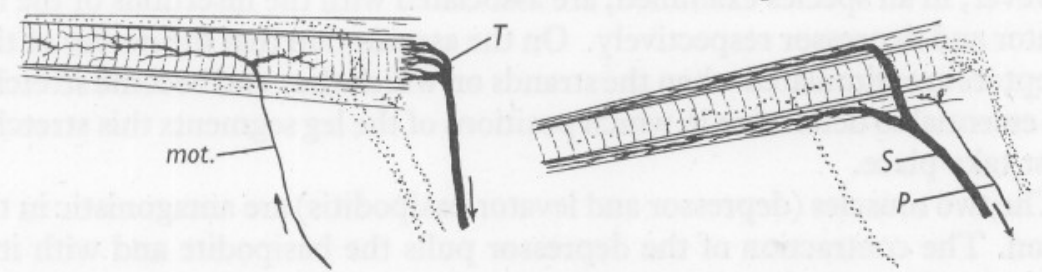

Text-fig. 4. (A, B) Diagrams of the movements of the legs in the thoracico-coxal articulation. The axis of these movements is represented as being perpendicular to the plane of the drawing and that of the coxo-basal articulation in this plane (actually these axes in different species can be inclined at various angles to the horizontal and vertical planes and can more or less deviate from being at right angles to one another). The drawings of the proximal parts of the thoracico-coxal receptors of Homarus type and Carcinus type show in $a$ and $b$ the nerve elements entering into action during the movements indicated in the diagram above in the same column. The elements out of action are drawn in dotted lines. The two strands flanking the receptor muscle in Carcinus are represented in diagrams by one line only. 
system, than in Homarus in which the same functions are performed by two organs one of which is of a primitive type with ordinary sensory cells situated outside the central nervous system.

It would be interesting to see whether intermediate stages in the evolution of receptors of the Homarus type to those of the Carcinus type can be found in other groups of Crustacea. One might suspect that in Homarus itself this evolution is at an early stage. The presence of two thick sensory fibres in its muscular receptor is suggestive in this respect. In the above considerations no account has been taken of differentiation in their function since in view of the abundance of their intermingling arborizations no distinct difference in localization of their endings could be ascertained. It is, however, not impossible that one of these elements has a tendency to distribute its branches on the more superficially situated connective tissue fibres and to pass farther in the distal direction. Conceivably, in the course of evolution, with the development of stronger strands alongside the muscle, this element has become the fibre $S$ responding to stretching of these strands and has supplanted the less efficient receptor of the older type which thus became obsolete and disappeared.

It is worth mentioning that in two instances, one somewhat doubtful but the other quite certain, I have noticed a small bipolar nerve cell among the nerve fibres of the muscular receptor in Carcinus. Such occasional cells might be vestiges of the primitive second receptor.

\section{Innervated strands (levator and depressor receptors)}

The levator and depressor receptors show differences in their arrangement as far as their proximal attachments are concerned. Their distal insertions, however, in all species examined, are associated with the insertions of the $\mathrm{mm}$. levator and depressor respectively. On the assumption that the nerves of these receptors are stimulated when the strands on which they end become stretched, it is essential to determine in which positions of the leg segments this stretching must take place.

The two muscles (depressor and levator basipoditis) are antagonistic in their action. The contraction of the depressor pulls the basipodite and with it the whole leg downwards and when the legs are pressed against the ground the animal is able to lift its body. In this position of the basipodite, as shown in diagram (Text-fig. 5A), the dorsally situated strand of the levator receptor must become extended, and consequently whenever the animal stands up and walks its levator receptors are likely to be in action.

The ventral strand, inserting on the tendon of the depressor muscle, will become relaxed when the latter contracts, but is extended when the basipodite is pulled upwards (Text-fig. $5 \mathrm{~B}$ ). It is, however, not so obvious as with the levator receptor when precisely during this movement the receptor nerves can be stimulated, because when the body is actively lifted the ventral strand 
is more slackened, compared with its state in the resting animal, and from this state it is unlikely to respond immediately to the contraction of $\mathrm{m}$. levator. It should, however, be borne in mind that as the animal walks the leg movements in the dorso-ventral plane are combined with those in the horizontal plane, and as the movements in the latter may exert some tension on the receptor strands they can contribute in bringing the leg segments into such a position that the depressor receptor can come into play. Thus, according to this interpretation the two innervated strands would be designed to regulate

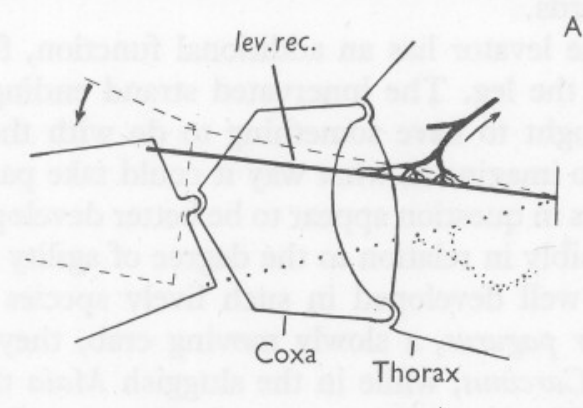

A

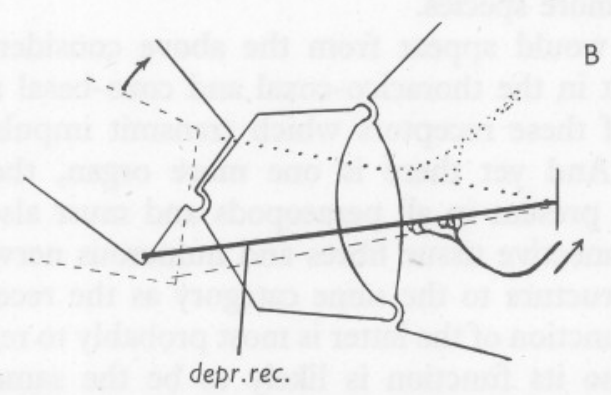

Text-fig. 5. Diagram of the movements of the legs in the coxo-basal articulation. The plane of this drawing is at right angles to that in Text-fig. 4. The position of the basipodite in the resting animal is indicated by interrupted lines. (A) Contraction of $\mathrm{m}$. depressor basipoditis. (B) Contraction of $\mathrm{m}$. levator basipoditis.

the action of the depressor and levator muscles, and it should be noted that the levator receptor would respond to the contraction of the depressor muscle and vice versa. The terms designating these organs relate therefore to their topographical connexions and not to their function. It is not proposed to change these names since they have been used in the description given previously, and moreover their anatomical relation is a fact whereas the assumptions concerning their function are as yet hypothetical.

Other hypotheses could also be put forward, as, for instance, that each of these receptors responds to variations of contraction of that muscle with which it is associated. There are two objections to this idea: first it implies that the 
stimulation of the receptors would not occur when the receptor strand is stretched but when it is slackened, which seems less likely; and secondly, it would not explain why the levator receptor has a richer innervation and in some species like Eupagurus and Palinurus appears to be a much more conspicuous organ. This feature fits the conception that the levator receptor controls the depressor muscle which has the important function of keeping the body above the ground as long as the animal is on the move, while the task of the levator muscle is only to lift the leg and keep it lifted when it is being shifted forwards.

It is true that the levator has an additional function, for it is the muscle which autotomizes the leg. The innervated strand ending with this muscle might thus be thought to have something to do with the autotomy. It is, however, difficult to imagine in what way it could take part in this process.

The two receptors in question appear to be better developed in some species than in others, possibly in relation to the degree of agility of the animals. In fact they are very well developed in such lively species as Eupagurus and Carcinus: in Cancer pagurus, a slowly moving crab, they appear to be less developed than in Carcinus, while in the sluggish Maia they are apparently absent altogether. Whether this is a general rule can only be established by a special study of more species.

To sum up, it would appear from the above considerations that every possible movement in the thoracico-coxal and coxo-basal articulations elicit stimuli in some of these receptors which transmit impulses to the central nervous system. And yet there is one more organ, the coxo-basipodite receptor, which is present in all peraeopods and must also play some role. Being made of connective tissue fibres and numerous nerve cells, it belongs according to its structure to the same category as the receptors in all other joints. Since the function of the latter is most probably to register the position of the segments, so its function is likely to be the same. Its apparently superfluous occurrence in the same articulation in which other receptors are present can perhaps be explained on the supposition that it responds to the movements of the leg when the animal is not walking and when no complicated co-ordination of leg movements is needed. When, however, adjustments of the locomotory mechanism are required, a finer apparatus must come into action.

The superiority of this finer apparatus lies evidently $(a)$ in the shifting of the cell bodies of all its neurons into the central nervous system, thus offering similar advantages as in the nervous system of vertebrates, and $(b)$ in the considerable thickness of the afferent fibres facilitating the speedy transmission of the impulses in the reflexes co-ordinating the movements of the legs. ${ }^{1}$ The

${ }_{1}$ The situation of the cell bodies of the receptor neurons in the thoracic ganglia could not yet be ascertained. The direction of the course of the thick sensory fibres of the muscular receptor traced in Homarus leads to a group of smaller cells, but not the smallest ones, situated laterally to the largest cells in the postero-ventral region of the ganglion. 
abundance and variety of these fibres is indicative of the complexity of their functions and is further evidence of a far advanced evolutionary stage of the coxal receptors compared with those consisting of rows of sensory nerve cells. In the latter it is only the variations in size of these cells and in thickness of their axons which point to some differences, probably of graded character, of their function, whereas in the three receptors in the coxa there are several nerves and the role of each of them poses a problem which can only be solved by physiological experiments. Structural differences only occasionally afford some clue. One point concerning the thinner fibre $P$ in the muscular receptor is worth mentioning. In crabs it can be seen that this fibre is confined to a small area of the same strand into which the thick fibre $S$ penetrates (Textfig. 5, Carcinus b), and as far as could be ascertained the end-filaments of the two fibres do not mix. Such a disposition would indicate that this fibre $P$ is unlikely to have an inhibitory or excitatory character and that it probably responds to the variations of tension of the same strand as the fibre $S$, but transmits it at a lesser speed. In the levator receptor the thick and thin nerve fibres also appear to have independent areas of termination, but the pictures of their distribution are less distinct owing to the abundance of various nerve branches. Moreover, fibres which look much alike can certainly be physiologically different. Since, for instance, the thick fibres of the levator receptor, each of them much thicker than the strand on which they end, are at least two in number, it seems unlikely that they would have an identical function.

Thus, as far as the histological evidence goes, it can be stated that if experiments could show that a proprioceptor in the coxal region is capable of transmitting impulses to several neurons in the central nervous system, to excite some of them and inhibit others, and to do it at different speeds, there would be no reason to question whether it has enough nerve elements for all these various functions.

The author gratefully acknowledges the grant received from the Royal Society. Thanks are due to the Marine Biological Laboratory, Plymouth, for all facilities provided for research, and to the Director, Dr F. S. Russell, F.R.S., for reading and criticizing the manuscript.

\section{SUMMARY}

In the coxal region of Eupagurus bernardus the following receptor organs have been found: (I) a muscular receptor spanning the thoracico-coxal articulation, its innervation, in which several neurons take part, being arranged on a similar pattern as in Carcinus; (2) two innervated elastic strands running along the bundles of $\mathrm{mm}$. levator and depressor basipoditis respectively and inserting into the tendons of these muscles; (3) a coxo-basipodite receptor consisting of connective tissue strand with numerous bipolar nerve cells ending on it. 
With the exception of the coxo-basipodite receptor,-all sensory neurons of these organs have their cell bodies located in the central nervous system.

It is suggested that these receptors convey impulses elicited by the movements of the legs and some hypotheses concerning the role of each of them are put forward.

\section{REFERENCES}

AleXandrowicz, J. S. \& Whitear, M. 1957. Receptor elements in the coxal region of Decapoda Crustacea. F. mar. biol. Ass. U.K., Vol. 36, pp. 603-28.

BARTH, G. I934. Untersuchungen über Myochordotonalorgane bei den dekapoden Crustaceen. Z. woiss. Zool., Bd. I45, pp. 576-624.

BURKE, W., 1954. An organ for proprioception and vibration sense in Carcinus maenas. f. exp. Biol., Vol. 31, pp. 127-38.

DiJKGraAF, S., I956. Kompensatorische Augenstieldrehungen und ihre Auslösung bei der Languste (Palinurus vulgaris). Z. vergl. Physiol., Bd. 38, pp. 491-520.

FLOREY, ELISABETH \& FLOREY, ERNST, I955. Microanatomy of the abdominal stretch receptors of the crayfish (Astacus fluviatilis L.). F. gen. Physiol. Vol. 39, pp. 69-85.

\section{EXPLANATION OF PLATE I}

All photographs were made from preparations of Eupagurus bernhardus stained with methylene blue, fixed in ammonium molybdate and mounted in xylol-dammar. Figs. I, 3, 5 and 6 are made with the same magnification but the respective preparations were obtained from animals of various sizes.

Fig. I. $M R$, thoracico-coxal receptor of the 2 nd left peraeopod in connexion with the thoracic ganglion. The thin fibre crossing obliquely the nerve trunk in the left lower corner is the strand of the levator receptor (displaced).

Fig. 2. Proximal part of the thoracico-coxal receptor of the 2 nd left peraeopod. $T$, fibre ending on the tendon.

Fig. 3. Thoracico-coxal receptor of the 2nd left peraeopod, showing its distal attachment.

Fig. 4. Thoracico-coxal receptor of the 5 th left peraeopod with nerve fibres branching before reaching the muscle. mot., motor nerve.

Fig. 5. Levator receptor of the 2 nd left peraeopod with four nerve branches ending on the strand; cf. Text-fig. 3B.

Fig. 6. Depressor receptor of the 3 rd peraeopod. This preparation was made from a much larger animal than that shown in fig. 5 .

Fig. 7. Part of the levator receptor of the 3 rd right peraeopod showing the nerve fibre at the point of meeting of the main and additional strands.

Fig. 8. Thick and thin fibre ending on the strand of the levator receptor. Same magnification as fig. 7 . 

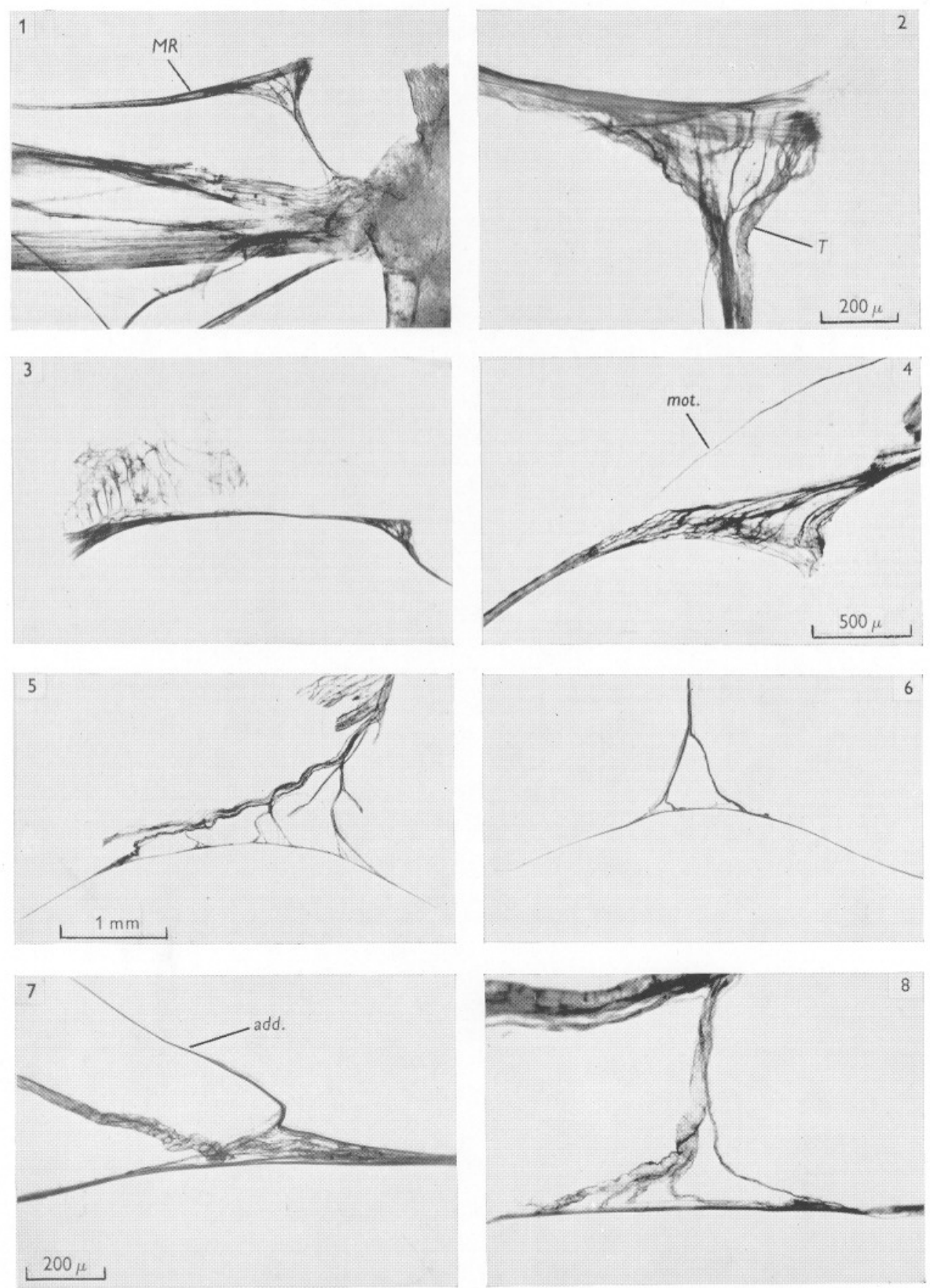

(Facing p. 396) 